\title{
Galur Isogenik Xanthomonas oryzae pv. oryzae Hasil Penyinaran Ultraviolet dan Potensinya Sebagai Penginduksi Resistensi Padi terhadap Penyakit Hawar Daun Bakteri
}

\author{
Isogenic Xanthomonas oryzae pv. oryzae Strain Resulted from \\ Ultraviolet Irradiation and Their Potency as Plant Resistance Inducer \\ Against Rice Bacterial Leaf Blight
}

\author{
Fitria Yuliani, Giyanto*, Kikin Hamzah Mutaqin \\ Institut Pertanian Bogor, Bogor 16680
}

\begin{abstract}
ABSTRAK
Penyakit hawar daun bakteri oleh Xanthomonas oryzae pv. oryzae merupakan salah satu penyakit penting pada tanaman padi dengan tingkat kerusakan mencapai 50\%. Salah satu upaya yang dilakukan untuk mengendalikan penyakit ini ialah menggunakan galur bakteri nonpatogen isogenik yang dapat menginduksi ketahanan tanaman. Penelitian ini bertujuan mendapatkan $X$. oryzae pv. oryzae isogenik menggunakan penyinaran ultraviolet dan mengevaluasi kemampuan isolat dalam menginduksi ketahanan tanaman padi. Biakan $X$. oryzae pv. oryzae dipapar dengan sinar UV selama 3, 5, 10 dan 15 menit. Sebanyak 99 koloni yang tumbuh diseleksi patogenisitasnya, selanjutnya dikonfirmasi identitasnya menggunakan primer XOR-F dan XOR-R2 sehingga didapat 16 galur isogenik. Produksi eksopolisakarida $X$. oryzae pv. oryzae isogenik berkisar antara 1.4 dan $9.8 \mathrm{mg} \mathrm{mL}^{-1}$, sedangkan tipe liarnya $6.0 \mathrm{mg} \mathrm{mL}^{-1}$. Lima galur terpilih (M313, M57, M101, M1513 dan M1515) menunjukkan penurunan virulensi $92.8-98.6 \%$. Aplikasi kelima galur tersebut pada bibit padi memperlihatkan masa inkubasi 6.6-5.4 hari setelah inokulasi (hsi), lebih pendek dibandingkan dengan tipe liar, yaitu 4.8 hsi. Perlakuan $X$. oryzae pv. oryzae isogenik juga mengakibatkan penekanan perkembangan penyakit dengan nilai AUDPC lebih kecil dibandingkan dengan tipe liar dan kontrol. Aplikasi $X$. oryzae pv. oryzae isogenik tidak memengaruhi pertumbuhan, tetapi meningkatkan produksi tanaman. Galur M101 memiliki masa inkubasi 5.7 hsi, nilai AUDPC paling rendah (615), dan bobot kering gabah (2.8 g per 100 bulir) lebih tinggi dibandingkan dengan tipe liarnya ( $2.0 \mathrm{~g}$ per $100 \mathrm{bulir})$.
\end{abstract}

Kata kunci: AUDPC, induksi ketahanan, masa inkubasi, patogenisitas

\begin{abstract}
Bacterial leaf blight (BLB) caused by Xanthomonas oryzae pv. oryzae is an important rice disease and may cause $50 \%$ plant damage. One approach to manage this disease is using isogenic nonpathogenic strain that can induce plant resistance. This study was conducted to obtain isogenic strains of $X$. oryzae pv. oryzae through ultraviolet irradiation and evaluate ability of the isolates in inducing plant resistance. Bacteria $X$. oryzae pv. oryzae were exposed to UV for 3, 5, 10 and $15 \mathrm{~min}$. A total of 99 colonies obtained were selected through pathogenicity tests, followed by confirmation using XOR-F and XOR-R2 primers. As much as 16 isogenic strain isolates were obtained with the ability to produce exopolysaccharides (EPS) ranges between 1.4-9.8 mg mL-1 compared to wild-type $6.0 \mathrm{mg} \mathrm{mL}^{-1}$. Five isogenic strains isolates (M313, M57, M101, M1513 and M1515) caused virulence reduction of 92.8$98.6 \%$. Application of those five isogenic isolates prolonged incubation period of X. oryzae pv. Oryzae,
\end{abstract}

*Alamat penulis korespondensi: Laboratorium Bakteriologi Departemen Proteksi Tanaman, Fakultas Pertanian,Institut Pertanian Bogor, Kampus IPB Dramaga, Bogor 16680

Tel: 0251-8376268, Faks : 0251-8629364, Surel: giyanto2@yahoo.com 
i.e. 6.6-5.4 days compared to the wild-type i.e. 4.8 days after inoculation. Suppression of disease progression was also observed with AUDPC value 615.0-827.5, which was lower than those caused by wild-type and control, i.e. 863.3 and 682.5 , respectively. Application of isogenic strain isolates did not affect plant growth but it increased plant productivity. Isogenic strain M101 was the best isolate with an incubation period of 5.7 days after inoculation, having the lowest AUDPC value (615.0), and yielded dry weight of 100 grains higher $(2.8 \mathrm{~g})$ than those of the wild-type $(2.0 \mathrm{~g})$.

Keywords: AUDPC, incubation period, pathogenicity, resistance inducer

\section{PENDAHULUAN}

Penyakit hawar daun bakteri (HDB) oleh Xanthomonas oryzae pv. oryzae merupakan salah satu penyakit utama tanaman padi. Bakteri ini menyerang pada fase pertumbuhan vegetatif dan generatif dan menimbulkan gejala berupa hawar berwarna cokelat keabuan pada daun. Luas serangan penyakit HDB di Indonesia selama periode Oktober 2011Maret 2012 mencapai 98\% (Ditjen TP 2012). $X$. oryzae pv. oryzae patotipe IV merupakan galur yang ganas dan banyak ditemukan di lapangan (Harfiah et al. 2015).

Salah satu upaya pengendalian penyakit tanaman ialah pemanfaatan bakteri nonpatogen isogenik (Rukayadi et al. 2000). Bakteri ini merupakan bakteri yang kehilangan kemampuan dalam menimbulkan penyakit akibat perubahan gen yang mengodekan virulensi yang dapat dihasilkan melalui mutasi.

Bakteri nonpatogen isogenik sebagai agens biokontrol lebih menguntungkan karena mutan akan berperilaku sama dengan tipe liarnya dalam merespons perubahan lingkungan (Wahyudi et al. 2011). Gangguan pada gen pembentukan eksopolisakarida menjadi salah satu target mutasi untuk menghasilkan galur isogenik. Eksopolisakarida berupa lendir terdapat pada permukaan sel dan sering dikaitkan dengan virulensi patogen (Lee et al. 2005). Gangguan pada gen pengatur produksi eksopolisakarida menyebabkan penurunan kemampuan galur bakteri isogenik menginfeksi inang sehingga diharapkan mampu berkompetisi dengan tipe liarnya dan mengaktifkan mekanisme ketahanan tanaman. Penelitian ini bertujuan mendapatkan galur $X$. oryzae pv. oryzae isogenik yang memiliki virulensi rendah melalui penyinaran ultraviolet dan mengevaluasi kemampuan galur isogenik untuk mengendalikan penyakit hawar daun bakteri pada tanaman padi.

\section{BAHAN DAN METODE}

\section{Induksi Penyinaran Ultraviolet $X$. oryzae pv. oryzae}

X. oryzae pv. oryzae patotipe IV (tipe liar) merupakan koleksi Balai Besar Penelitian Tanaman Padi, Sukamandi. Bakteri ini diperbanyak dalam $50 \mathrm{~mL}$ medium cair sukrosa kentang dan digojog \pm 22 jam sampai kerapatan sel $10^{8} \mathrm{cfu} \mathrm{mL}^{-1}\left(\mathrm{OD}_{600}=0.2\right)$. Sebanyak $100 \mu \mathrm{L}$ suspensi bakteri disebar pada medium agar-agar sukrosa kentang (ASK) menggunakan glass bead selanjutnya dipapar sinar UV-C (100-280 nm) pada ESCO laminar model EQU/03-EHC dengan waktu yang berbeda, yaitu 3, 5, 10, dan 15 menit. Selanjutnya biakan bakteri diinkubasi pada suhu $28^{\circ} \mathrm{C}$ di tempat gelap selama 48 jam. Koloni yang tumbuh dipindahkan pada medium ASK dan selanjutnya dipapar sinar UV dengan perlakuan yang sama dengan sebelumnya (Thein dan Prathuangwong 2010).

\section{Seleksi Galur X. oryzae pv. oryzae Isogenik}

Uji Patogenisitas. Suspensi galur $X$. oryzae pv. oryzae isogenik dan tipe liar $\left(10^{8} \mathrm{cfu} \mathrm{mL}^{-1}\right)$ masing-masing diinokulasikan pada daun padi berumur 30 hari setelah tanam (HST). Gunting dicelupkan ke dalam suspensi bakteri, selanjutnya digunakan untuk menggunting daun. Pengamatan panjang hawar dilakukan pada hari ke-14 setelah inokulasi.

Konfirmasi Galur $X$. oryzae pv. oryzae Isogenik. Konfirmasi $X$. oryzae pv. oryzae isogenik dilakukan dengan teknik PCR menggunakan 
pasangan primer spesifik XOR-F(5'GCATGACGTCATCGTCCTG-3') dan XORR2(5'-CTCGGAGCTATATGCCGTGC-3'). Proses PCR dilakukan dengan tahapan denaturasi awal $95{ }^{\circ} \mathrm{C}$ selama 2 menit; diikuti 29 siklus terdiri atas tahapan denaturasi $95^{\circ} \mathrm{C}$ selama 30 detik, aneling pada suhu $63{ }^{\circ} \mathrm{C}$ selama 30 detik, dan pemanjangan pada suhu $72{ }^{\circ} \mathrm{C}$ selama 1 menit; serta ekstensi akhir $72{ }^{\circ} \mathrm{C}$ selama 7 menit (Keshavarz et al. 2011).

Produksi Eksopolisakarida. Sebanyak 16 galur $X$. oryzae pv. oryzae isogenik diremajakan di dalam $10 \mathrm{~mL}$ medium cair sukrosa kentang dan digojog 24 jam. Sebanyak $1 \mathrm{~mL}$ suspensi bakteri dipindahkan ke tabung mikro $2 \mathrm{~mL}$ selanjutnya disentrifugasi pada suhu $4{ }^{\circ} \mathrm{C}$ dengan kecepatan $6000 \mathrm{rpm}$ selama 20 menit. Supernatan dipindahkan ke tabung mikro $2 \mathrm{~mL}$ dan ditambahkan etanol dingin (96\%) sebanyak 2 kali volume supernatan dan didiamkan satu malam. Selanjutnya tabung mikro disentrifugasi pada suhu $4{ }^{\circ} \mathrm{C}$ kecepatan $6000 \mathrm{rpm}$ selama 20 menit. Pelet dikeringkan di dalam oven $\left(55^{\circ} \mathrm{C}\right)$ dan ditimbang bobot keringnya (Nudyanto dan Zubaidah 2015).

\section{Induksi Ketahanan Tanaman Padi} Menggunakan $X$. oryzae pv. oryzae Isogenik

Percobaan ini disusun dalam rancangan acak lengkap. Perlakuan terdiri atas inokulasi 5 galur $X$. oryzae pv. oryzae isogenik terpilih, kontrol positif (X. oryzae pv. oryzae patotipe IV), dan kontrol negatif (akuades steril) dengan 8 ulangan, masing-masing terdiri atas 1 unit tanaman (Tabel 1). Percobaan dilakukan di lahan percobaan Departemen Proteksi Tanaman IPB Bogor (6 30’ LS, 106 30 30' BT) dengan ketinggian tempat $150 \mathrm{~m}$ dpl.

Aplikasi $X$. oryzae pv. oryzae isogenik tahap I dilakukan pada 25 benih padi IR-64 dengan merendamnya di dalam suspensi sel bakteri $\left(10^{8} \mathrm{cfu} \mathrm{mL}^{-1}\right)$ selama 48 jam. Selanjutnya benih padi disemai pada tanah steril. Bibit berumur 14 hari dipindahkan ke ember plastik yang berisi tanah sawah steril. Aplikasi tahap II dilakukan pada tanaman padi berumur 35 HST dengan penyiraman suspensi sel bakteri sebanyak $20 \mathrm{~mL}$ tanaman $^{-1} \mathrm{di}$ sekitar perakaran tanaman.
Inokulasi $X$. oryzae pv. oryzae patotipe IV dilakukan pada daun bendera (85 HST) dengan metode pengguntingan daun menggunakan gunting steril yang telah dicelupkan pada biakan cair $X$. oryzae pv. oryzae patotipe IV $\left(10^{8} \mathrm{cfu} \mathrm{mL}^{-1}\right)$. Tanaman yang telah diinokulasi disungkup dengan plastik bening selama 3 hari untuk menjaga kelembapan mikro di sekitar tanaman.

Pengamatan Penyakit Hawar Daun Bakteri

Pengamatan masa inkubasi dimulai dari hari pertama setelah inokulasi sampai gejala penyakit terlihat pada tanaman. Keparahan penyakit (KP) merupakan persentase luasnya jaringan tanaman terserang patogen dari total luasan yang diamati, yang dinyatakan dalam rumus berikut:

$$
\mathrm{KP}=\frac{\sum_{\mathrm{i}=1}^{\mathrm{n}}\left(\mathrm{n}_{i} \times \mathrm{v}_{i}\right)}{\mathrm{Z} \times \mathrm{N}} \times 100 \% \text {, dengan }
$$

$\mathrm{KP}$, keparahan penyakit; $\mathrm{n}_{i}$, jumlah jaringan terserang pada setiap skala; $\mathrm{v}_{i}$, skala serangan; $\mathrm{Z}$, skala serangan tertinggi; dan $\mathrm{N}$, total jaringan yang diamati. Skala perhitungan berdasarkan standard evolution system (IRRI 2014). Pengamatan dilakukan setiap 3 hari dimulai 3 hari setelah inokulasi dan dihentikan setelah gejala hawar sampai pangkal daun.

Area Under Disease Progress Curve (AUDPC) adalah jumlah penyakit pada setiap perlakuan dari pengamatan pertama hingga pengamatan terakhir. Penghitungan AUDPC menggunakan rumus:

$$
\text { AUDPC }=\sum_{i=0}^{n}\left[\frac{y_{i}+y_{i+1}}{2}\right] \times\left(t_{i+1}-t_{i}\right) \text {, dengan }
$$

$Y_{i}$, insidensi penyakit pada waktu ke-i; $t_{i}$, waktu pengamatan ke-i.

Pengukuran tinggi dan jumlah anakan padi dilakukan setiap minggu sampai minggu ke-10

Tabel 1 Galur $X$. oryzae pv. oryzae isogenik terpilih dan lama penyinaranUV-C $(100-280 \mathrm{~nm})$

\begin{tabular}{cc}
\hline $\begin{array}{l}\text { Lama penyinaran UV } \\
\text { (menit) }\end{array}$ & $\begin{array}{c}\text { Kode galur } \\
\text { X. oryzae pv. oryzae }\end{array}$ \\
\hline 0 & Patotipe IV (tipe liar) \\
3 & M313 \\
5 & M57 \\
10 & M101 \\
15 & M1513 dan M1515 \\
\hline
\end{tabular}


setelah tanam. Jumlah anakan produktif dihitung menggunakan rumus:

$$
\text { Anakan produktif }=\frac{\mathrm{A}}{\mathrm{B}} \times 100 \% \text {, dengan }
$$

A, jumlah anakan yang menghasilkan malai; dan B, jumlah anakan keseluruhan. Bobot kering gabah ditentukan dengan menghitung bobot malai yang telah dikeringkan. Pengamatan juga dilakukan terhadap bobot kering 100 bulir padi.

\section{Analisis Data}

Data penyakit hawar daun dianalisis menggunakan program statistical analisys system (SAS) versi 9.0 dan diuji lanjut menggunakan DMRT pada taraf 5\%.

\section{HASIL}

Induksi penyinaran UV menghasilkan 99 galur isogenik. Jumlah koloni yang tumbuh semakin sedikit dengan semakin lamanya waktu pemaparan UV (Tabel 2). Galur M101, M1513, dan M1515 memperlihatkan perubahan bentuk, demikian juga warna menjadi kuning pucat dan lendir lebih sedikit dibandingkan dengan tipe liarnya (Gambar 1).

Dari 99 galur bakteri yang diuji dengan teknik PCR diperoleh 16 galur yang positif sama dengan tipe liarnya. Uji patogenisitas 26 galur hasil penyinaran UV menunjukkan penurunan virulensi 25.4-98.6\%. Galur M1513 dan M101 memperlihatkan produksi eksopolisakarida paling rendah, yaitu $1.4 \mathrm{mg} \mathrm{mL}^{-1}$ dan $1.6 \mathrm{mg} \mathrm{mL}^{-1}$ berbeda nyata dengan tipe liar $6.0 \mathrm{mg} \mathrm{mL}^{-1}$. Hasil seleksi didapat 5 galur terpilih (M313, M57, M101,

Tabel 2 Jumlah koloni bakteri $X$. oryzae pv. oryzae isogenik pada lama penyinaran UV-C (100-280 nm) yang berbeda

\begin{tabular}{cc}
\hline $\begin{array}{l}\text { Lama penyinaran UV } \\
\text { (menit) }\end{array}$ & $\begin{array}{c}\text { Jumlah koloni } \\
\text { yang tumbuh }\end{array}$ \\
\hline 3 & 50 \\
5 & 23 \\
10 & 18 \\
15 & 8 \\
\hline Total isolat & 99 \\
\hline
\end{tabular}

M1513, dan M1515) yang menunjukkan penurunan virulensi sebesar 92.8-98.6\% dan penurunan produksi eksopolisakarida dibandingkan tipe liarnya (Tabel 3).

\section{Induksi Ketahanan Galur $X$. oryzae pv. oryzae Isogenik}

Aplikasi galur isogenik mampu memperpanjang masa inkubasi $X$. oryzae pv. oryzae dan memperlihatkan intensitas penyakit yang lebih rendah dibandingkan dengan aplikasi tipe liarnya. Hasil pengamatan menunjukkan lama masa inkubasi tidak menggambarkan rendahnya intensitas penyakit (Tabel 4). Masa inkubasi paling lama terdapat pada perlakuan galur M1515, yaitu 6.6 HSI sedangkan tipe liar 4.9 HSI, tetapi menunjukkan intensitas penyakit yang tidak berbeda nyata dengan aplikasi tipe liar. Galur M101 mempunyai masa inkubasi 5.7 HSI dan memperlihatkan intesitas penyakit terendah dari semua perlakuan, yaitu $66.1 \%$ berbeda nyata dengan aplikasi tipe liar (85.5\%). Galur M101 juga memiliki nilai AUDPC yang paling rendah (615.0) sedangkan tipe liar 863.3. Nilai AUDPC yang rendah menunjukkan perkembangan penyakit lebih lambat.

Aplikasi galur isogenik tidak berpengaruh nyata terhadap pertumbuhan, tetapi berpengaruh pada produksi tanaman (Tabel 5). Sebanyak 5 galur isogenik menunjukkan kenaikan bobot kering bulir per malai yang nyata daripada tipe liarnya. Bobot bulir per malai berkisar antara $1.1 \mathrm{~g}$ dan $1.4 \mathrm{~g}$, sedangkan tipe liarnya hanya $0.5 \mathrm{~g}$ dan kontrol 1.1 g. Galur M101 memperlihatkan bobot kering 100 bulir tertinggi dan berbeda nyata dengan tipe liarnya.

\section{PEMBAHASAN}

Radiasi ultraviolet mampu melakukan penetrasi ke dinding sel yang mengakibatkan perubahan komposisi asam nukleatnya. Terbentuknya timina dimer memengaruhi proses replikasi menyebabkan terjadinya mutasi. Mutasi dengan penyinaran ultraviolet berakibat pada kesalahan menyandi protein jika tidak bersifat letal sehingga menimbulkan 


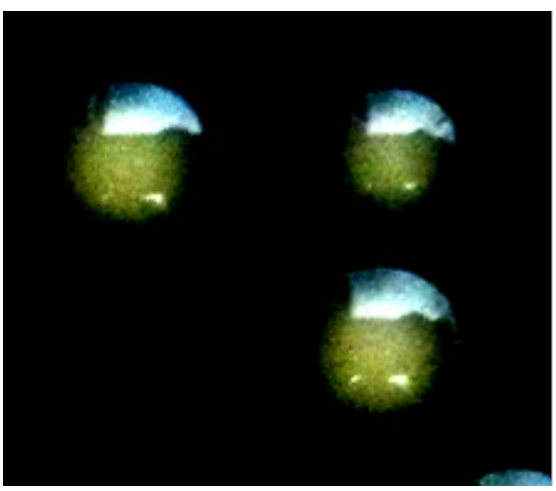

a

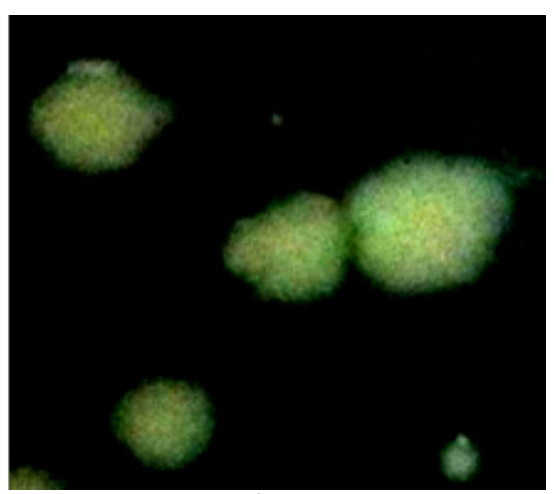

$\mathrm{b}$

Gambar 1 Morfologi Xanthomonas oryzae pv. oryzae M101 berubah dibandingkan dengan tipe liarnya pada medium agar-agar sukrosa kentang ( $5 \mathrm{hsi}$ ), perubahan terlihat pada bentuk, warna, pinggiran, dan lendir pada permukaan koloni. a, Koloni patotipe IV; b, Galur M101.

Tabel 3 Karakteristik fenotip galur Xanthomonas oryzae pv. oryzae isogenik

\begin{tabular}{cccccc}
\hline $\begin{array}{c}\text { Lama Penyinaran } \\
\text { UV } \\
\text { (menit) }\end{array}$ & $\begin{array}{c}\text { Kode galur } \\
\text { X. oryzae pv. } \\
\text { oryzae }\end{array}$ & Uji PCR & $\begin{array}{c}\text { Panjang hawar } \\
(\mathrm{cm})\end{array}$ & $\begin{array}{c}\text { Penurunan } \\
\text { virulensi }\end{array}$ & $\begin{array}{c}\text { Produksi } \\
\text { EPS } \\
\left(\mathrm{mg} \mathrm{mL}^{-1}\right)\end{array}$ \\
\hline 0 & $\begin{array}{c}\text { Patotipe } 4 \\
\text { (tipe liar) }\end{array}$ & + & $13.8 \mathrm{a}$ & 0.0 & $6.0 \mathrm{c}$ \\
& M36 & + & $7.9 \mathrm{c}$ & 42.8 & $8.4 \mathrm{~b}$ \\
& M313 & + & $1.0 \mathrm{e}$ & 92.8 & $2.6 \mathrm{gh}$ \\
3 & M323 & + & $4.0 \mathrm{~d}$ & 71.0 & $3.4 \mathrm{ef}$ \\
& M331 & + & $6.4 \mathrm{c}$ & 53.6 & $2.0 \mathrm{ij}$ \\
& M334 & + & $3.1 \mathrm{~d}$ & 77.5 & $2.8 \mathrm{gh}$ \\
5 & M338 & + & $6.9 \mathrm{c}$ & 50.0 & $3.8 \mathrm{e}$ \\
& M57 & + & $0.3 \mathrm{e}$ & 97.8 & $5.8 \mathrm{c}$ \\
& M511 & + & $7.8 \mathrm{c}$ & 43.5 & $3.2 \mathrm{fg}$ \\
& M514 & + & $6.9 \mathrm{c}$ & 50.0 & $9.8 \mathrm{a}$ \\
10 & M517 & + & $10.3 \mathrm{~b}$ & 25.4 & $6.2 \mathrm{c}$ \\
& M101 & + & $0.5 \mathrm{e}$ & 96.4 & $1.6 \mathrm{j}$ \\
& M102 & + & $0.5 \mathrm{e}$ & 96.4 & $3.6 \mathrm{ef}$ \\
& M105 & + & $0.7 \mathrm{e}$ & 94.9 & $2.4 \mathrm{hi}$ \\
& M153 & + & $1.4 \mathrm{e}$ & 89.9 & $4.6 \mathrm{~d}$ \\
& M1513 & + & $0.2 \mathrm{e}$ & 98.6 & $1.4 \mathrm{j}$ \\
& M1515 & + & $0.2 \mathrm{e}$ & 98.6 & $2.2 \mathrm{hi}$ \\
\hline
\end{tabular}

+, berdasarkan pada uji PCR isolat berkerabat dengan X. oryzae pv. oryzae.

Angka dalam satu kolom diikuti huruf yang sama tidak berbeda nyata pada Uji DMRT $\alpha 5 \%$.

penampakan fenotip yang berbeda dari keadaan normalnya dan dapat diwariskan pada keturunannya (Rajeshwar et al. 2002). Mutasi yang dihasilkan berupa salah baca kode genetik (Hockbeger 2002). Absorbsi radiasi ultraviolet menyebabkan terbentuknya ikatan kovalen dua molekul timin yang saling berdekatan (timina dimer) pada suatu urutan DNA (Rastogi et al. 2010).
Pemaparan UV pada penelitian ini menghasilkan perubahan morfologi pada beberapa galur, penurunan kemampuan galur dalam menginfeksi inang dan penurunan produksi eksopolisakarida. Mutan Streptomyces fradiae NRRL-2702 mengalami perubahan morfologi dari tipe liarnya setelah diberi pemaparan UV (Khaliq et al. 2007). Uji patogenisitas mutan $X$. oryzae pv. oryzae 
Tabel 4 Aplikasi galur Xanthomonas oryzae pv. oryzae isogenik terhadap perkembangan penyakit hawar daun bakteri

\begin{tabular}{lccc}
\hline $\begin{array}{l}\text { Galur isogenik } \\
\text { X. oryzae pv. orzae }\end{array}$ & $\begin{array}{c}\text { Masa inkubasi } \\
(\mathrm{HSI})\end{array}$ & $\begin{array}{c}\text { Keparahan penyakit } \\
(\%)\end{array}$ & Nilai AUDPC \\
\hline M313 & $5.7 \mathrm{~b}$ & $71.7 \mathrm{~b}$ & 617.5 \\
M57 & $5.4 \mathrm{bc}$ & $76.7 \mathrm{ab}$ & 827.5 \\
M101 & $5.7 \mathrm{~b}$ & $66.1 \mathrm{~b}$ & 615.0 \\
M1513 & $6.5 \mathrm{a}$ & $74.4 \mathrm{ab}$ & 624.2 \\
M1515 & $6.6 \mathrm{a}$ & $70.3 \mathrm{~b}$ & 632.1 \\
Patotipe IV (tipe liar) & $4.9 \mathrm{c}$ & $85.6 \mathrm{a}$ & 863.3 \\
Kontrol & $5.6 \mathrm{~b}$ & $72.2 \mathrm{~b}$ & 682.5 \\
\hline
\end{tabular}

Angka dalam satu kolom diikuti huruf yang sama tidak berbeda nyata pada Uji DMRT $\alpha$ 5\%.

HSI, hari setelah inokulasi; AUDPC, Area Under Disease Progress Curve.

Tabel 5 Aplikasi galur Xanthomonas oryzae pv. oryzae isogenik terhadap pertumbuhan dan hasil tanaman padi

\begin{tabular}{lccccc}
\hline $\begin{array}{l}\text { Galur isogenik } \\
\text {. oryzae pv. orzae }\end{array}$ & $\begin{array}{c}\text { Tinggi } \\
\text { tanaman } \\
(\mathrm{cm})\end{array}$ & $\begin{array}{c}\text { Jumlah } \\
\text { anakan }\end{array}$ & $\begin{array}{c}\text { Anakan } \\
\text { produktif } \\
(\%)\end{array}$ & $\begin{array}{c}\text { Bobot bulir } \\
\text { per malai } \\
(\mathrm{g})\end{array}$ & $\begin{array}{c}\text { Bobot } \\
100 \mathrm{bulir} \\
(\mathrm{g})\end{array}$ \\
\hline M313 & $93.2 \mathrm{a}$ & $26.2 \mathrm{a}$ & $69.0 \mathrm{a}$ & $1.1 \mathrm{ab}$ & $2.4 \mathrm{~d}$ \\
M57 & $92.4 \mathrm{a}$ & $21.5 \mathrm{a}$ & $78.4 \mathrm{a}$ & $1.0 \mathrm{ab}$ & $2.5 \mathrm{~cd}$ \\
M101 & $94.4 \mathrm{a}$ & $25.2 \mathrm{a}$ & $72.3 \mathrm{a}$ & $1.1 \mathrm{ab}$ & $2.8 \mathrm{a}$ \\
M1513 & $93.1 \mathrm{a}$ & $21.5 \mathrm{a}$ & $76.7 \mathrm{a}$ & $1.4 \mathrm{a}$ & $2.6 \mathrm{bc}$ \\
M1515 & $92.9 \mathrm{a}$ & $25.0 \mathrm{a}$ & $69.2 \mathrm{a}$ & $1.3 \mathrm{ab}$ & $2.6 \mathrm{bc}$ \\
Patotipe IV (tipe liar) & $95.1 \mathrm{a}$ & $26.4 \mathrm{a}$ & $69.5 \mathrm{a}$ & $0.5 \mathrm{c}$ & $2.0 \mathrm{e}$ \\
Kontrol & $92.8 \mathrm{a}$ & $24.0 \mathrm{a}$ & $74.9 \mathrm{a}$ & $1.0 \mathrm{~b}$ & $2.6 \mathrm{ab}$ \\
\hline
\end{tabular}

Angka dalam satu kolom diikuti huruf yang sama tidak berbeda nyata pada Uji DMRT $\alpha$ 5\%.

Hrp-(M5) menunjukkan mutan masih koloni mutan yang lebih kecil dibandingkan menimbulkan gejala penyakit pada padi, dengan tipe liarnya pada medium yang namun lebih rendah daripada tipe liarnya. mengandung sukrosa.

Wahyudi (2011) menduga karena adanya keterlibatan gen-gen lain yang menentukan sifat virulen $X$. oryzae pv. oryzae.

Eksopolisakarida (EPS) merupakan polimer dari gula dengan bobot molekul tinggi yang disekresikan oleh mikroorganisme ke lingkungan eksternalnya. EPS dari bakteri berperan dalam menghambat translokasi unsur hara dan air, melindung bakteri dalam keadaan ekstrem, dan menetralisir senyawa yang dikeluarkan oleh tanaman (Lee et al. 2005). Pada penelitian ini penurunan produksi EPS menjadi indikator terjadinya gangguan genetik pada faktor pembentukan EPS. Thein dan Prathuangwong (2010) menyatakan penurunan produksi EPS mutan $X$. oryzae pv. oryzae hasil penyinaran UV dilihat dari ukuran
Galur isogenik diduga mampu menekan pertumbuhan tipe liarnya dengan menginduksi ketahanan tanaman. Berdasarkan hasil penelitian terlihat masa inkubasi bakteri tipe liar lebih panjang pada perlakuan galur isogenik. Thein dan Prathuangwong (2010) melaporkan galur M-690 hasil mutasi UV bakteri $X$. oryzae pv. oryzae mampu menginduksi ketahanan tanaman terhadap penyakit HBD dengan intensitas penyakit $36.7 \%$ dibandingkan dengan tipe liarnya $46.7 \%$.

Aplikasi galur isogenik tidak berpengaruh terhadap pertumbuhan, tetapi berpengaruh terhadap hasil tanaman yang ditunjukkan dengan adanya peningkatan dibandingkan dengan aplikasi tipe liarnya. Peningkatan 
produksi tanaman diduga akibat aktifnya mekanisme ketahanan tanaman. Mulsanti et al. (2014) melaporkan bahwa bobot kering 100 bulir padi IR-64 berkisar antara $2.4 \mathrm{~g}$ dan $2.57 \mathrm{~g}$.

Dari hasil yang didapat terlihat bahwa rendahnya produksi EPS tidak diiringi dengan penurunan virulensi galur isogenik. EPS merupakan salah satu faktor virulensi $X$. oryzae pv. oryzae sehingga penurunan produksi EPS tidak menyebabkan hilangnya seluruh kemampuan patogen dalam menimbulkan penyakit. Hal ini disebabkan adanya keterlibatan gen-gen lain yang menentukan sifat virulen $X$. oryzae pv. oryzae (Wahyudi et al. 2011). Penurunan virulensi dan produksi EPS pada galur isogenik terpilih yang diaplikasikan pada padi mampu menginduksi ketahanan tanaman. Hal ini terlihat dari perlambatan perkembangan $X$. oryzae $\mathrm{pv}$. oryzae berdasarkan nilai AUDPC dengan intensitas penyakit yang tidak berbeda nyata dengan kontrol. Keberadaan galur isogenik tidak memberikan dampak negatif terhadap pertumbuhan dan hasil tanaman.

Galur isogenik yang didapat dari penelitian ini masih berada pada tahap penelitian dasar sehingga masih diperlukan pendalaman untuk menentukan potensinya sebagai agens hayati seperti kestabilan virulensi, respons beragam varietas padi, dan dinamika populasinya di dalam jaringan tanaman padi.

\section{DAFTAR PUSTAKA}

[Ditjen TP] Direktorat Jendral Tanaman Pangan. 2012. Evaluasi prakiraan serangan OPT utama tanaman padi dan jagung [Internet]. [diunduh 2016 Januari 24]. Tersedia pada: http://tanamanpangan. deptan.go.id/index.php/.

Harfiah W, Abadi AL, Qurata'aini L. 2015. Ketahanan lima galur padi (Oryza sativa L.) terhadap dua isolat Xanthomonas oryzae pv. oryzae penyebab penyakit hawar daun bakteri pada tanaman padi. J HPT. 3(2): 2338-4336.

Hockberger PE. 2002. A history of ultraviolet photobiology for humans, animals and microorganisms. Photobiol. 76: 561579. DOI: https://doi.org/10.1562/00318655(2002)0760561AHOUPF2.0.CO2.

[IRRI] International Rice Research Institute. 2014. Standart evaluation system for rice (5th ed). Philippines (PH): Agricultural Research Los Banos University.

Keshavarz K, Sijam K, Ahmad M, Abidin Z, Hashim H, Nazerian E. 2011. Rapid identification and differention of Xanthomonas oryzae pv. oryzae strain with primer 16S-23S rDNA from rice fields in Peninsular Malaysia. Asian J Plant Pathol. 5(2): 93-99. DOI: https://doi.org/10.3923/ ajppaj.2011.93.99.

Khaliq S, Kalsoom A, Muhammad AG, Ruqia I, Ahmad MK,Muhammad M. 2007. Change incolony morphology and kinetic softy losin production after $\mathrm{UV}$ and gammairradiation mutagenesis of Streptomycesfradiae NRRL-2702. Microbiol Res. 164: 469-477. DOI: https:// doi.org/10.1016/j.micres.2007.02.005.

Lee BM, Park DS, Kang JG, Kim ES, Song IC, Park UH, Yoon JH, Hahn BS, Koo GB, Koh JS. 2005. The genome sequence of Xanthomonas oryzae pathovar oryzae KACC10331, the bacterial blight pathogen of rice. Nucleic Acids Res. 33(2):577-586. DOI: https://doi.org/10.1093/nar/gki206.

Mulsanti IW, Wahyuni S, Sembiring H. 2014. Hasil Padi dari empat kelas benih yang berbeda. Penelitian Pertanian Tanaman Pangan. 33(3): 169-176.

Nudyanto A, Zubaidah E. 2015. Isolasi bakteri asam laktat penghasil eksopolisakarida dari kimchi. J Pangan Agroindustri. 3(2): 743-748.

Rukayadi Y, Suwanto A, Tjahjono, Harling R. 2000. Survival and epiphytic fitness of a nonpathogenic mutant of Xathomonas campestris pv. glycines. Appl Environ Microbiol. 66(3): 1183-1189. DOI: https://doi.org/10.1128/AEM.66.3.11831189.2000.

Rajeshwar PS, Donat PH. 2002. UV-induced DNA damage and repair. Photochem Photobiol Sci. 1: 225-236. DOI: https:// doi.org/10.1039/b201230h. 
Rastogi RP, Richa, Kumar A, Tyagi MB, Rajeshwar PS. 2010. Molecular mechanisms of ultraviolet radiationinduced DNA damage and repair. J Nucleic Acids. doi:10.4061/2010/592980. DOI: https://doi.org/10.4061/2010/592980.

Thein A, Prathuangwong S. 2010. Novel strains of Xanthomonas oryzae pv. oryzae uv mutated induce systemic resistance in rice against bacterial leaf blight disease. Kasetsart J. 44:1026-1043.

Wahyudi AT, Meliah S, Nawangsih AA. 2011. Xanthomonas oryzae pv. oryzae bakteri penyebab hawar daun pada padi: isolasi, karakterisasi, dan telaah mutagenesis dengan transposon. Makara Sains. 15(1):89-96. 